\title{
Day Times Picomole per Liter
}

National Cancer Institute

\section{Source}

National Cancer Institute. Day Times Picomole per Liter. NCI Thesaurus. Code C111187.

Days times picomoles per liter. 